\title{
British Heart Foundation surveys (1987 and 1989) of United Kingdom treatment policies for acute myocardial infarction
}

\author{
Rory Collins, Desmond Julian
}

\begin{abstract}
Consultant physicians and cardiologists were surveyed early in 1987 and 1989 to document the management policies for the treatment of acute myocardial infarction in United Kingdom hospitals and to assess the influence of major clinical trials on these policies. The response rate to both these surveys was high (84\% (1178 physicians) in 1987 and $76 \%$ (982 physicians) in 1989). The percentage of physicians that reported using antiplatelet therapy "routinely" in acute myocardial infarction rose from $9 \%$ in 1987 to $84 \%$ in 1989 while those who reported using it "rarely or never" fell from $42 \%$ to $3 \%$. Similarly, "routine" use of fibrinolytic therapy rose from $2 \%$ to $68 \%$, and use "rarely or never" fell from $53 \%$ to $3 \%$. This increase in the reported use of fibrinolytic therapy was accompanied by greater certainty about its efficacy and relative safety and by a general widening of the indications for its use. The use of other treatments in acute myocardial infarction (for example, the general use of anticoagulants, $\beta$ blockers, nitrates, calcium antagonists, or prophylactic antiarrhythmic agents) seemed to change little during this period, although the routine use of coronary angiography and oral anticoagulants after fibrinolytic therapy fell substantially between 1987 and 1989 (from $23 \%$ to $4 \%$, and from $24 \%$ to $7 \%$ respectively).

Fibrinolytic and antiplatelet therapy were accepted into the routine management of myocardial infarction during a relatively short period that coincided with the reporting of several positive controlled trial results. Clinical trials have rarely been seen to have had such a great impact on practice. In this case the rapid acceptance of the trial results may have been due to the consistency and reliability of the estimates of the size of the benefits (and risks) of therapy seen in these unusually large studies.
\end{abstract}

More than 100000 patients are admitted to United Kingdom hospitals each year with a diagnosis of suspected acute myocardial infarction. ${ }^{1}$ Of these, a few tens of thousands will die during the hospital admission or in the subsequent months. Consequently, a substantial research effort is being made to identify treatments for acute myocardial infarction (such as $\beta$ blockers, ${ }^{2}$ fibrinolytic therapy, ${ }^{3-6}$ antiplatelet therapy, ${ }^{4}$ vasodilator therapy, ${ }^{7}$ anticoagulants, ${ }^{8}$ calcium antagonists, ${ }^{9}$ antiarrhythmics, ${ }^{10}$ and angioplasty ${ }^{1-13}$ ) that might reduce morbidity and mortality. There is, however, little direct evidence ${ }^{14-16}$ about current cardiological practice in the United Kingdom, or of any changes that might be occurring as the results from major clinical trials emerge. To investigate these points we conducted two surveys among United Kingdom consultant physicians and cardiologists of their treatment policies for acute myocardial infarction, first in early 1987 and then again in early 1989.

\section{Methods}

1987 SURVEY

The index of hospitals section of The Medical Directory 1985 was used to help identify all consultant physicians and cardiologists in Britain and Northern Ireland who might be involved in the care of patients with acute myocardial infarction. In mid-1986 a regionally representative random sample of 50 of these physicians was sent a pilot questionnaire to gauge the likely response and to modify any questions that caused confusion or other difficulties. A modified five page questionnaire was then sent in December 1986 to all the consultants identified and a reminder was sent in March 1987 to those who had not replied. Of 1984 consultants written to initially, 1248 replied to the first letter and a further 417 replied to the reminder $(84 \%$ overall response rate). Four hundred and eighty four stated that they did not routinely treat acute myocardial infarction and three had retired $(25 \%$ of those replying to the first letter and $41 \%$ of those replying to the reminder, which suggests that many of the remaining non-responders do not 
routinely treat acute myocardial infarction: indeed, in the 1989 survey 145 of the 319 nonresponders did reply and $40 \%$ did not treat acute myocardial infarction). This leaves 1178 who provided details of their current approach to the treatment of acute myocardial infarction in early 1987.

\section{SURVEY}

The same questionnaire was sent again in 1989 to the 1178 consultants who stated in response to the first survey that they treated acute myocardial infarction and to the 319 who had not replied to the first questionnaire. Of these 1497 consultants, 787 replied to the first letter and a further 346 replied to the reminder $(76 \%$ overall response rate). One hundred and fifty one stated that they did not routinely treat acute myocardial infarction (or were retired), leaving 982 that did.

\section{Results}

DESCRIPTION OF THE RESPONDENTS

In both surveys combined, $11 \%$ of the respondents described themselves as cardiologists and a further $17 \%$ as general physicians with a special interest in cardiology. Hence the vast majority $(72 \%)$ of consultant physicians treating acute myocardial infarction in the United Kingdom do not have a special interest in cardiology. Almost all (99\%) of the respondents were either fellows or members of the Royal College of Physicians and $46 \%$ had doctorates. Thirty five per cent worked in specialist cardiac centres or university teaching hospitals. Most $(88 \%)$ admitted patients to some form of coronary care unit, but only about one third had access to facilities for cardiac catheterisation (36\%) or coronary angioplasty $(26 \%)$ and there was little reported change in these facilities between the surveys.

Randomised clinical trials of the treatment of acute myocardial infarction are being conducted in many hospitals in the United Kingdom and more than one third of the consultants reported being involved in at least one such study (most being multicentre collaborations).

\section{TREATMENT USED FOR ACUTE MYOCARDIAL}

INFARCTION

The physicians surveyed were asked whether, provided there was no specific medical contraindication, they used any of a variety of treatments "routinely for most patients", "sometimes (or as part of a randomised trial)", or "rarely or never" in patients with suspected acute myocardial infarction. Table 1 shows the distribution of responses to these questions.

For anticoagulants, $\beta$ blockers, nitrates, calcium antagonists, and prophylactic antiarrhythmics there was little difference between the results of the 1987 and the 1989 surveys, and the results of the two surveys are considered together. Anticoagulation: similar proportions of physicians reported that they used subcutaneous heparin "routinely", "sometimes", and "rarely". In contrast, intravenous heparin and oral anticoagulants were used routinely by $\leqslant 10 \%$. $\beta$ Blockers: these were started routinely in hospital by about a quarter of the consultants and most of the rest used them sometimes. $\beta$ Blockade was, however, rarely started with an initial intravenous dose. Nitrates: oral nitrates were used routinely by about one quarter of the physicians, but intravenous nitrates were used routinely by only about $10 \%$. Most of the other physicians reported that they used nitrates only when there were further clinical indications other than merely suspected acute myocardial infarction. Calcium antagonists and prophylactic antiarrhythmics: these were not often used routinely in acute myocardial infarction (6\% and $2 \%$ respectively in 1987 , and $7 \%$ and $1 \%$ respectively in 1989), and more than half of the consultants responded that they rarely or never used them.

For antiplatelet and fibrinolytic treatment, in contrast, there seems to have been a

Table 1 Physicians' responses to questions relating to current practice (1178 in 1987 and 982 in 1989):

"In the treatment of ACUTE MYOCARDIAL INFARCTION, do you generally use any of the following agents, provided there are no specific medical contraindications?"

\begin{tabular}{|c|c|c|c|c|c|c|}
\hline \multirow[b]{3}{*}{ Treatments } & \multicolumn{6}{|c|}{ Percentage of physicians who replied that they used treatment: } \\
\hline & \multicolumn{2}{|c|}{ Routinely for most patients } & \multicolumn{2}{|c|}{$\begin{array}{l}\text { Sometimes (or as part } \\
\text { of a randomised trial) }\end{array}$} & \multicolumn{2}{|c|}{ Rarely or never } \\
\hline & 1987 & 1989 & 1987 & 1989 & 1987 & 1989 \\
\hline Antiplatelet & 9 & 84 & 49 & 13 & 42 & 3 \\
\hline $\begin{array}{l}\text { Fibrinolytic therapy: } \\
\text { Intravenous } \\
\text { Intracoronary }\end{array}$ & $\begin{array}{l}2 \\
0\end{array}$ & $\begin{array}{r}68 \\
1\end{array}$ & $\begin{array}{r}45 \\
6\end{array}$ & $\begin{array}{r}28 \\
3\end{array}$ & $\begin{array}{l}53 \\
94\end{array}$ & $\begin{array}{r}3 \\
96\end{array}$ \\
\hline $\begin{array}{l}\text { Anticoagulants } \\
\text { Subcutaneous heparin } \\
\text { Intravenous heparin } \\
\text { Oral }\end{array}$ & $\begin{array}{r}41 \\
6 \\
4\end{array}$ & $\begin{array}{r}38 \\
11 \\
3\end{array}$ & $\begin{array}{l}34 \\
55 \\
40\end{array}$ & $\begin{array}{l}40 \\
58 \\
43\end{array}$ & $\begin{array}{l}25 \\
38 \\
56\end{array}$ & $\begin{array}{l}22 \\
32 \\
54\end{array}$ \\
\hline $\begin{array}{l}\beta \text { Blockers: } \\
\text { Oral } \\
\text { Intravenous }\end{array}$ & $\begin{array}{r}25 \\
4\end{array}$ & $\begin{array}{r}31 \\
3\end{array}$ & $\begin{array}{l}63 \\
38\end{array}$ & $\begin{array}{l}58 \\
30\end{array}$ & $\begin{array}{l}11 \\
58\end{array}$ & $\begin{array}{l}11 \\
67\end{array}$ \\
\hline $\begin{array}{l}\text { Nitrates: } \\
\text { Cutaneous } \\
\text { Oral } \\
\text { Intravenous }\end{array}$ & $\begin{array}{r}3 \\
23 \\
5\end{array}$ & $\begin{array}{r}2 \\
27 \\
12\end{array}$ & $\begin{array}{l}38 \\
66 \\
75\end{array}$ & $\begin{array}{l}32 \\
64 \\
80\end{array}$ & $\begin{array}{l}59 \\
11 \\
20\end{array}$ & $\begin{array}{r}66 \\
9 \\
8\end{array}$ \\
\hline $\begin{array}{l}\text { Calcium antagonists: } \\
\text { Oral } \\
\text { Intravenous }\end{array}$ & $\begin{array}{l}6 \\
1\end{array}$ & $\begin{array}{l}7 \\
1\end{array}$ & $\begin{array}{l}77 \\
28\end{array}$ & $\begin{array}{l}73 \\
21\end{array}$ & $\begin{array}{l}18 \\
71\end{array}$ & $\begin{array}{l}20 \\
78\end{array}$ \\
\hline Prophylactic antiarrhythmics & 2 & 1 & 48 & 44 & 50 & 55 \\
\hline
\end{tabular}


Table 2 Factors that might influence use of intravenous fibrinolytic therapy among those physicians who used it "routinely" or "sometimes" (530 in 1987 and 933 in 1989)

\begin{tabular}{|c|c|c|c|c|c|c|}
\hline \multirow[b]{3}{*}{ Patient characteristics } & \multicolumn{6}{|c|}{ Percentage of physicians replying: } \\
\hline & \multicolumn{2}{|l|}{ Yes } & \multicolumn{2}{|c|}{ Not sure } & \multicolumn{2}{|l|}{ No } \\
\hline & 1987 & 1989 & 1987 & 1989 & 1987 & 1989 \\
\hline $\begin{array}{l}\text { Site of infarct } \\
\text { Age of patient } \\
\text { Delay from symptoms }\end{array}$ & $\begin{array}{l}11 \\
69 \\
93\end{array}$ & $\begin{array}{r}6 \\
54 \\
99\end{array}$ & $\begin{array}{r}13 \\
12 \\
3\end{array}$ & $\begin{array}{l}6 \\
9 \\
1\end{array}$ & $\begin{array}{r}76 \\
20 \\
4\end{array}$ & $\begin{array}{r}89 \\
37 \\
1\end{array}$ \\
\hline
\end{tabular}

substantial change in the physicians' policies between 1987 and 1989. Routine use of antiplatelet therapy increased from only $9 \%$ of physicians in 1987 to $84 \%$ in 1989 -and almost all who did not use it "routinely" in 1989 reported that they did use it "sometimes" for particular patients. A similarly striking increase in fibrinolytic treatment has been seen, with "routine" use increasing from $2 \%$ in 1987 to $68 \%$ in 1989 , with most of those who did not use fibrinolytic therapy "routinely" in 1989 using it "sometimes" for particular patients. Hence, by 1989 almost all of those physicians reported that, for all or some of their patients, they would use antiplatelet and fibrinolytic therapy ( $97 \%$ and $96 \%$ respectively).

Given the considerable research interest in fibrinolytic treatment over the past few years, factors that might influence its use were investigated in greater detail in both surveys. Those consultants who said they used it routinely or sometimes were asked if their decision to do so was influenced by the site of infarction, by the patient's age, or by the delay from onset of symptoms to presentation (table 2). Few of the respondents were definitely influenced by the site of infarction, and the proportions that were so influenced decreased from $11 \%$ in 1987 to $6 \%$ in 1989 . The age of the patient influenced about two-thirds of the consultants who answered this question in 1987 but influenced only half of those who responded in 1989 . Of those influenced by age in 1987 , only $18 \%$ treated patients aged over 70 and only $2 \%$ treated those aged over 75 (fig 1). Treatment of elderly patients had been adopted more widely by 1989 with $42 \%$ treating those aged over 70 and $8 \%$ those aged over 75 . Delay from the onset of symptoms to presentation seems to play an important part in determining whether fibrinolytic therapy is used: $93 \%$ and $99 \%$ of respondents in 1987 and 1989 respectively said that it influenced their decision. Patients presenting after six hours were, however, much more likely to be treated in 1989 than they were in 1987 (46\% in 1989 compared with only $18 \%$

Figure 1 Influence of age of patient on use of fibrinolytic therapy. Percentage of physicians for whom age is a factor ( 285 of 415 replying to 285 of 415 replying to
this question in 1987 and this question in 1987 and
486 of 907 in 1989) who used fibrinolytic therapy in patients of different ages.

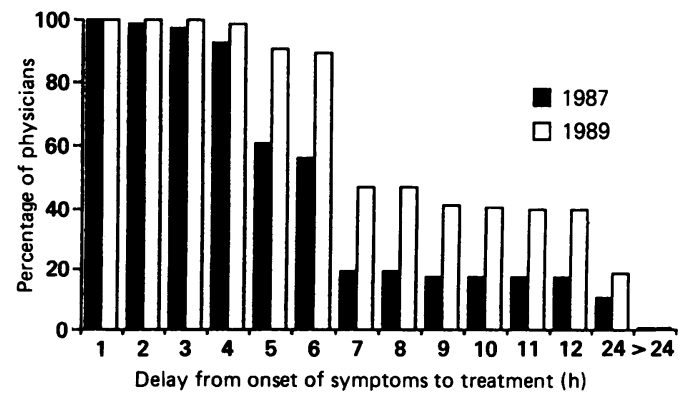

Figure 2 Influence of delay from onset of symptoms on use of fibrinolytic therapy. Percentage of physicians for whom delay is a factor (405 of 436 replying to this question in 1987 and 909 of 924 in 1989) who used fibrinolytic therapy after different lengths of delay.

in 1987), and by 1989 about a fifth were using fibrinolytic therapy in patients presenting up to 24 hours after pain onset (fig 2).

About a third of the responders used heparin routinely after fibrinolytic therapy, about a third used it sometimes, and about a third rarely or never used it, and there was little change between 1987 and 1989 (table 3). In $1987,24 \%$ of physicians stated that they routinely used oral anticoagulants after fibrinolysis, but this had fallen to only $7 \%$ by 1989 . As with the acute use of antiplatelet therapy, there was a big increase between 1987 and 1989 in the reported use of antiplatelet therapy after fibrinolysis, with $88 \%$ using it routinely in 1989. Interestingly, both coronary angiography and coronary angioplasty after fibrinolysis were reported to be less commonly used in 1989.

Table 4 shows the responses to enquiries about the reasons why some physicians use fibrinolytic therapy "rarely or never". In 1987 about a half of the 594 consultants who rarely or never used fibrinolytic therapy stated that they were unsure about either the beneficial or the adverse effects of treatment. A quarter considered there to be no clear evidence of an early mortality benefit, and more than a half remained unconvinced about any long-term benefit. Very few considered there to be an increased risk of reinfarction, stroke, hypotension, or arrhythmia $(9 \%, 11 \%, 11 \%$, and $6 \%$ respectively), but more than a third thought that fibrinolytic therapy increased the risk of non-cerebral bleeds and of allergies. Nearly a third believed that the currently available intravenous fibrinolytic therapy regimens were not practical in their hospital. By 1989, far fewer physicians $(n=31)$ "rarely or never" used fibrinolytic therapy, and even among those there was a consensus that fibrinolysis can save lives. For this small number of physicians, the main concerns seemed to relate to the risk of non-cerebral bleeds, as well as to the impracticability of fibrinolytic treatment in their hospitals.

Responses to the questionnaire were considered among various categories grouped according to various features of the physicians (including age, qualifications, degree of specialisation, type of hospital), but this did not identify any group that was much more likely or much less likely to use any of the treatments listed in table 1 (data not shown). 
Table 3 Treatment used after fibrinolytic therapy among those physicians that used it "routinely" or "sometimes" (530 in 1987 and 933 in 1989)

\begin{tabular}{|c|c|c|c|c|c|c|}
\hline \multirow[b]{3}{*}{ Treatments } & \multicolumn{6}{|c|}{ Percentage of physicians replying: } \\
\hline & \multicolumn{2}{|c|}{ Routinely } & \multicolumn{2}{|c|}{ Sometimes } & \multicolumn{2}{|c|}{ Rarely or never } \\
\hline & 1987 & 1989 & 1987 & 1989 & 1987 & 1989 \\
\hline $\begin{array}{l}\text { Subcutaneous heparin } \\
\text { Intravenous heparin } \\
\text { Oral anticoagulants } \\
\text { Antiplatelet therapy } \\
\text { Coronary angiography } \\
\text { Coronary angioplasty }\end{array}$ & $\begin{array}{r}23 \\
40 \\
24 \\
18 \\
23 \\
4\end{array}$ & $\begin{array}{r}30 \\
31 \\
7 \\
88 \\
4 \\
0\end{array}$ & $\begin{array}{l}22 \\
32 \\
33 \\
59 \\
48 \\
58\end{array}$ & $\begin{array}{r}25 \\
27 \\
26 \\
8 \\
62 \\
54\end{array}$ & $\begin{array}{l}55 \\
28 \\
44 \\
23 \\
29 \\
37\end{array}$ & $\begin{array}{r}45 \\
42 \\
67 \\
5 \\
33 \\
46\end{array}$ \\
\hline
\end{tabular}

\section{Discussion}

SUMMARY OF RESULTS

The high response to these surveys of United Kingdom consultant physicians and cardiologists routinely treating acute myocardial infarction makes it likely that the results are at least reasonably representative of the opinions of those responsible for the treatment of acute myocardial infarction in hospital. Of course, such surveys provide information only about what people say they do and not necessarily about what they actually do, but in some cases it is possible to determine how reasonable the responses are. For example, where available, the total sales of particular drugs or less representatively the reported use of treatments among patients being studied in experimental protocols can be compared with the survey responses. For fibrinolytic therapy, sales data do reinforce the results of the surveys. ${ }^{17} \mathrm{Be}-$ tween 1984 and 1987 streptokinase sales were unchanging and sufficient to treat only a few thousand patients with acute myocardial infarction each year, even if it is assumed that none of this streptokinase was used for other indications. But during 1988 there was a substantial increase in sales such that in 1989 the equivalent of more than 50000 patient treatments were sold in England and Wales. Information from multicentre clinical trials ${ }^{2418}$ conducted during this period in Britain also supports the survey responses, in particular confirming the very low routine use of intravenous $\beta$ blockers, of intravenous nitrates, and (at least before 1989) of antiplatelet agents.

The results of the first survey contrast strongly with a similar survey carried out in spring 1987 among United States physicians, ${ }^{1920}$ in which $66 \%$ of 1065 respondents said that they used fibrinolytic therapy routinely at that time. The percentages of United States cardiologists who said that they routinely used prophylactic antiarrhythmics (29\% in the United States survey versus $2 \%$ in our 1987 United Kingdom survey), intravenous $\beta$ blockers ( $16 \% v 4 \%$ ), oral $\beta$ blockers $(77 \%$ v $25 \%)$, and antiplatelet therapy $(63 \%$ aspirin and $21 \%$ dipyridamole $v 9 \%$ for any antiplatelet) in hospital were also substantially higher than among their United Kingdom counterparts. This may reflect different attitudes to therapeutic intervention in acute myocardial infarction in the two countrieswith United Kingdom doctors generally being more sceptical. But another possible explanation is that because four fifths of the United States physicians surveyed did not reply the results of the United States questionnaire may be somewhat unrepresentative. The United States survey also found that although most of the physicians who responded did report that they were using fibrinolytic therapy routinely, they were doing so in only a very small proportion of the patients that presented to them with suspected acute myocardial infarction. This finding is reinforced by $1989 / 1990$ sales data for the United States which indicate that the number of fibrinolytic doses sold in the United States was only about twice as many as in the United Kingdom, ${ }^{17}$ despite about a fivefold greater number of myocardial infarction hospital admissions. ${ }^{1}$

IMPACT OF TRIAL RESULTS ON CLINICAL PRACTICE Discrepancies between the results of clinical trials and the application of those results to clinical practice are not uncommon. It is not known which factors determine the translation of clinical trial results into routine medical practice, but two factors that may be important are the perceived reliability of the study results and the balance between the size of any benefits and the size of any risks.

Many previous trials have failed through inadequate sample size to provide convincing evidence as to whether the treatment under investigation produced a medically worthwhile effect or not. ${ }^{21} 22$ The large GISSI-1 study reported a highly significant reduction in mortality with fibrinolytic therapy in the Lancet in

Table 4 Attitudes about intravenous fibrinolytic therapy among those consultants who "rarely or never" used it (594 in 1987 and 31 in 1989)

\begin{tabular}{|c|c|c|c|c|c|c|}
\hline \multirow[b]{3}{*}{ Physician attitudes } & \multicolumn{6}{|c|}{ Percentage of physicians replying: } \\
\hline & \multicolumn{2}{|l|}{ Agree } & \multicolumn{2}{|c|}{ Not sure } & \multicolumn{2}{|c|}{ Disagree } \\
\hline & 1987 & 1989 & 1987 & 1989 & 1987 & 1989 \\
\hline $\begin{array}{l}\text { Intravenous fibrinolytic therapy does not reduce: } \\
\text {-early mortality } \\
\text {-long-term mortality }\end{array}$ & $\begin{array}{l}28 \\
52\end{array}$ & $\begin{array}{l}13 \\
13\end{array}$ & $\begin{array}{l}51 \\
43\end{array}$ & $\begin{array}{l}39 \\
52\end{array}$ & $\begin{array}{r}21 \\
5\end{array}$ & $\begin{array}{l}48 \\
35\end{array}$ \\
\hline $\begin{array}{l}\text { Intravenous fibrinolytic therapy increases risk of: } \\
\text { - reinfarction } \\
\text { - stroke } \\
\text { - non-cerebral bleed } \\
\text {-allergy } \\
\text { - hypotension } \\
\text { - arrhythmia } \\
\text {-other adverse event }\end{array}$ & $\begin{array}{r}9 \\
11 \\
42 \\
32 \\
11 \\
6 \\
2\end{array}$ & $\begin{array}{r}0 \\
10 \\
43 \\
14 \\
5 \\
0 \\
0\end{array}$ & $\begin{array}{l}50 \\
54 \\
42 \\
47 \\
58 \\
58 \\
72\end{array}$ & $\begin{array}{l}60 \\
57 \\
29 \\
52 \\
58 \\
63 \\
57\end{array}$ & $\begin{array}{l}41 \\
35 \\
16 \\
21 \\
32 \\
36 \\
26\end{array}$ & $\begin{array}{l}40 \\
33 \\
29 \\
33 \\
37 \\
37 \\
43\end{array}$ \\
\hline Treatment is not practicable in my hospital & 32 & 26 & 22 & 19 & 46 & 56 \\
\hline
\end{tabular}


January $1986,{ }^{3}$ yet by the time of our first survey (that is, about 12 months later) this had not led to widespread use. Perhaps it is that the delay between the publication of promising results and their main effect on clinical practice in the United Kingdom is measured in years rather than in months (particularly if, as was the case with GISSI-1, United Kingdom doctors are not involved in the study). It may be, however, that individual trials on their own are not wholly convincing (indeed, the editorial ${ }^{23}$ accompanying the GISSI-1 report stated "it is a good principle never to base clinical practice on a single clinical trial"), and that it was the confirmation of the GISSI-1 results by several other positive fibrinolytic therapy trials ${ }^{4-6}$ (involving many United Kingdom hospitals) that convinced British physicians to use fibrinolytic therapy routinely.

The need for independent confirmation may explain why the use of intravenous $\beta$ blockers in acute myocardial infarction has not been adopted widely into routine United Kingdom clinical practice. For this treatment has only been clearly shown to reduce mortality in the ISIS-1 trial, ${ }^{2}$ with no other trial of intravenous $\beta$ blockers large enough to detect reliably an effect of the size seen. (In contrast, several trials of oral $\beta$ blockers started after the acute event showed a significant mortality benefit, ${ }^{24}$ and such treatment is used widely.) It may be, however, that the proportional reduction in mortality seen with intravenous $\beta$ blockers was considered to be too small (15\% in ISIS-1 among relatively low risk patients, with a lower $95 \%$ confidence limit for this estimate that did not clearly exclude "no worthwhile benefit," compared with a very reliably demonstrated reduction of about $25 \%$ with fibrinolytic therapy among both high and low risk patients) to outweigh the perceived risks. The balance between the perceived benefits and perceived risks of treatment may be an important influence on the uptake of clinical trial results. Indeed, it seems likely to explain why, despite results being available from only one clinical trial in acute myocardial infarction, ${ }^{4}$ antiplatelet therapy (which was observed to reduce mortality by about as much as fibrinolytic therapy, but with fewer side effects) has been so widely and so rapidly accepted into routine clinical practice. In contrast, uncertainty about the risk: benefit ratio of fibrinolytic therapy may have been important in delaying its widespread adoption and may have limited treatment to those patients for whom the benefits were considered likely to be greatest. Concerns about the safety of fibrinolytic therapy at the time of the first survey in early 1987 seemed to have abated by early 1989 (perhaps due to generally reassuring results emerging from each of the fibrinolytic trials), with the result that not only did many more doctors report that they were using fibrinolytic therapy routinely but also that it was being used in a larger proportion of patients.

About a quarter of the physicians who reported "rarely or never" using fibrinolytic therapy said that one reason was that it was not practicable in their hospitals. This factor may also have played a part in determining the relative speed of uptake of fibrinolytic and of antiplatelet therapies. Low dose oral aspirin is cheap and easy to give, whereas fibrinolytic therapy is costly (even unpatented streptokinase is about $£ 80$, while the patented fibrinolytic agents are about $£ 500$ for anistreplase and about $£ 800$ for tissue plasminogen activator) and involves an intravenous infusion. Those doctors and hospitals that were reluctant to use fibrinolytic therapy because of cost and other practical issues may, therefore, have started to use it in some of their patients only after the benefits became overwhelmingly clear. Some uncertainty still remains as to the cost effectiveness of fibrinolytic therapy in certain categories of patient (for example, those presenting late after the onset of symptoms, or the elderly) and as a result many such patients are not treated. This may be resolved by further consideration of the current trial results, preferably in systematic overviews, ${ }^{25}$ and/or by further clinical trials (such as ISIS-3, EMERAS, and LATE) of fibrinolytic versus control in those categories of patient in which uncertainty remains.

In conclusion, the present survey results document a dramatic change in the treatment of acute myocardial infarction in United Kingdom hospitals between 1987 and 1989. In spite of some scepticism about the influence of clinical trials on clinical practice, it is apparent that their findings can produce rapid and substantial changes in treatment, provided the results are seen to be reliable and to indicate medically worthwhile benefits that outweigh any serious risks or other difficulties. We thank all those doctors who co-operated with the survey by
completing and returning the questionnaire; the British Heart completing and returning the questionnaire; the British Heart
Foundation for their support; the ISIS trial office (Paul Appleby, Foundation for their support; the ISIS trial office(Paul Appleby, Heather Halls, Deborah Jackson) in the MRC/ICRF Clinical
Trial Service Unit, University of Oxford, for processing the Trial Service Unit, University of Oxford, for processing the
questionnaires; Richard Peto and Peter Sleight for their helpful questionnaires; Richard Peto and Peter Sleight for
comments; and Gale Mead for typing the article.

1 Hospital in-patient enquiry. Summary tables. London: Department of Health and Social Security, 1984.

2 ISIS-1 Collaborative Group. Randomised trial of intravenous atenolol among 16,027 cases of suspected acute myocardial infarction: ISIS-1. Lancet 1986;ii:57-66.

3 Gruppo Italiano per lo Studio della Streptochinasi nell'Infarto miocardico (GISSI). Effectiveness of intravenous thrombolytic treatment in acute myocardial infarction. Lancet 1986;i:397-402.

4 ISIS-2 (Second International Study of Infarct Survival) Collaborative Group. Randomised trial of intravenous streptokinase, oral aspirin, both, or neither among 17,187 streptokinase, oral aspirin, both, or neither among 17,187
cases of suspected acute myocardial infarction: ISIS-2. cases of suspected acu
Lancet 1988;ii:349-60.

5 AIMS Trial Study Group. Effect of intravenous APSAC on mortality after acute myocardial infarction: preliminary report of a placebo-controlled trial. Lancet 1988;i:545-9.

6 ASSET Study Group. Trial of tissue plasminogen activator for mortality reduction in acute myocardial infarction. Lancet 1988;ii:525-30.

7 Yusuf S, Collins R, MacMahon S, Peto R. Effect of intravenous nitrates on mortality in acute myocardial infarction: an overview of the randomised trials. Lancet 1988;i:1088-92.

8 MacMahon S, Collins R, Knight C, et al. Reduction in major morbidity and mortality by heparin in acute myocardial infarction [Abstract]. Circulation 1988;78:1I-98.

9 Held PH, Y usuf S, Furberg CD. Calcium channel blockers in acute myocardial infarction and unstable angina: an in acute myocardial infarction and

10 MacMahon S, Collins R, Peto R, et al. Effects of prophylactic lidocaine in suspected acute myocardial infarction: an lidocaine in suspected acute myocardial infarction: an
overview of results from the randomised controlled trials. overview of results from
$J A M A$ 1988;260:1910-6.

11 Simoons ML, Arnold AER, Betriu A, et al. Thrombolysis with tissue plasminogen activator in acute myocardial with tissue plasminogen activator in acute myocardial infarction: no additional benefit from immediate percuct

12 TIMI Study Group. Comparison of invasive and con- 
servative strategies after treatment with intravenous tissue plasminogen activator in acute myocardial infarction. Results of the Thrombolysis in Myocardial Infarction (TIMI) Phase II trial. N Engl J Med 1989;320:618-27.

13 Topol EJ, Califf RM, George BS, et al. A randomized trial of imed, Califf RM, George BS, et al. A randomized trial of immediate versus delayed elective angioplasty after intravenous tissue plasminogen activator in acure

14 Baber NS, Julian DG, Lewis JA, Rose G. Beta-blockers after myocardial infarction: have trials changed practice? after myocardial infarction

15 Hutchison SJ, Cobbe SM. Management of myocardial infarction in Scotland: have clinical trials changed practice? BMJ 1987;294:1261.

16 Burrell CJ, Skehan JD, Cowley ML, Barrett CW, Mills PG. Districts' use of thrombolytic agents. BMJ 1990;300: 237-8.

17 Streptokinase quarterly sales in England and Wales. Source: IMS Audit Data (Hospital sales).

18 Wilhelmsen L, Collins R, Peto R, Sleight P for the ISIS Trials Collaborative Group. Drug treatment in hospital and at discharge in the ISIS-1 and ISIS-2 trials [abstract] Eur Heart $J$ 1989;10(abstract suppl):116.
19 Hlatky MA, Cotugno HE, Mark DB, et al. Trends in physician management of uncomplicated acute myocardial infarction, 1970 to 1987 . Am J Cardiol 1988;61:515-8.

20 Hlatky MA, Cotugno H, O'Connor C, et al. Adoption of thrombolytic therapy in the management of acute myocardial infarction. Am J Cardiol 1988;61:510-4.

21 Yusuf $S$, Collins $R$, Peto $R$, et al. Intravenous and intracoronary fibrinolytic therapy in acute myocardial intracoronary fibrinolytic the infarction: overview and side-effects from 33 randomized controlled trials. Eur

22 Yusuf S, Collins R, Peto R. Why do we need some large, simple randomized trials? Stat Med 1984;3:409-20.

23 Streptokinase in acute myocardial infarction. Lancet Streptokinase in

24 Yusuf S, Peto R, Lewis R, Collins R, Sleight P. Beta blockade during and after myocardial infarction: an overview of the randomized trials. Prog Cardiovasc Dis 1985;27:335-7

25 Collins R, Gray R, Godwin J, Peto R. Avoidance of large biases and large random errors in the assessment of moderate treatment effects: the need for systematic overviews. Stat Med 1987;6:245-50. 